\title{
Improved cell culture propagation of Amyloodinium ocellatum
}

\author{
Daniel J. Oestmann ${ }^{1, *}$, Donald H. Lewis ${ }^{2}$ \\ 11150 Beamer Rd \#416, Houston, Texas 77089, USA \\ ${ }^{2}$ Department of Veterinary Pathobiology, Texas A\&M University, College Station, Texas 77843, USA
}

\begin{abstract}
A system for cultivating Amyloodinium ocellatum was developed using aggregates of red drum Sciaenops ocellatus dorsal fin cells in suspension. Tomonts harvested from infected fish using density gradient centrifugation in Percoll ${ }^{\circledR}$ were placed in saltwater media ( 30 ppt) containing antibiotics (penicillin $100 \mathrm{IU} \mathrm{ml}^{1}$, streptomycin $100 \mathrm{mg} \mathrm{ml}^{-1}$ ). Microbe-free infective dinospores emerging from the tomonts were used to infect red drum cell aggregates. Dinospores attached and transformed into trophonts on the cell aggregates, developing into normal size $(80 \mu \mathrm{m})$ trophonts in saltwater media (10 ppt). Trophont infected cell aggregates were placed in increased saltwater concentration ( $30 \mathrm{ppt}$ ) at $48 \mathrm{~h}$ incubation to induce the release of trophonts and their encystment as tomonts. Tomonts were separated from the cellular debris by saltwater media washing and Percoll ${ }^{*}$ density gradient centrifugation. Tomonts were then incubated to produce a second generation of dinospores. The parasite was maintained in vitro for 10 complete life cycles with no observed decreased viability using this system.
\end{abstract}

KEY WORDS: Amyloodinium Protozoa Propagation Cell culture

\section{INTRODUCTION}

Amyloodinium ocellatum is an obligate dinoflagellate ectoparasite of marine and euryhaline warm water fishes (Lawler 1979, Paperna 1980, Sindermann 1990, Noga et al. 1991). Upon reaching 60 to $90 \mu \mathrm{m}$, each trophont releases from the fish to produce an encysted tomont. The tomont undergoes division to produce up to 256 free-swimming infective dinospores (Brown 1934, Nigrelli 1936, Brown \& Hovasse 1946). This triphasic life cycle (parasitic feeding trophont/encysted reproductive tomont/free-swimming infective dinospore) results in an amplification of the infestation in mariculture operations, resulting in high morbidity and rapid mortality (Lawler 1979, Paperna 1980, Sindermann 1990).

In order to study this economically important parasite, an in vitro propagation technique is essential. In vitro infections of Amyloodinium ocellatum (DC-1 strain) have been maintained using gnotobiotic guppies Poecilia reticulata (Noga \& Bower 1987) and G1B

\footnotetext{
·E-mail: oestmann@hal-pc.org
}

cell culture (Noga 1987, 1992). However, Texas (USA) Gulf Coast $A$. ocellatum originating from red drum $S_{C i}$ aenops ocellatus was not amenable to cultivation by these procedures.

Preliminary studies determined that dinospores would neither transform efficiently nor grow to full size on red drum dorsal fin cell (RDFC) monolayers. Therefore, a technique was developed to grow RDFC as aggregates in suspension, while slowly acclimating them to a saline environment. The aggregates provided a 3-dimensional structure upon which the dinospores transformed efficiently and grew to full size trophonts.

Parameters of in vitro propagation methods for U.S. Gulf Coast isolates must balance the wide tolerance of the parasite with the intolerance of RDFC to salinity variation (Paperna 1984, Noga 1987). Preliminary studies determined that the Gulf Coast strain of Amyloodinium ocellatum does not tolerate cell culture media or fetal bovine serum growth supplement, while red drum cells will not survive long in saltwater media without cell culture media and growth supplements. Furthermore, the incubation temperature must be suf- 
ficiently high to provide for parasitic growth and reproduction before red drum cells die, but not so high that the parasite grows too fast and destroys the cell aggregates by feeding activity.

\section{MATERIALS AND METHODS}

Cell aggregate growth (Thursday through Tuesday, Days 1 through 6). Cellular aggregates were prepared from a heterologous cell line of RDFC. Seven-day-old monolayers were trypsinized and the cell suspension dispensed into four $25 \mathrm{~cm}^{2}$ cell culture flasks containing a bottom coat of $3 \mathrm{ml}$ marine agar. The marine agar prevented adhesion of the cells to the flask and the salt in the agar was thought to leach into the media and gradually acclimate the cells to a more saline environment, eliminating the acclimation period required in the procedure described by Noga $(1987,1992)$. The cells aggregated when incubated in $7 \mathrm{ml} \mathrm{L}-15$ cell culture media (BioWhittaker, Inc., Walkersville, MD, USA) supplemented with $15 \%$ fetal bovine serum and $1 \%$ L-glutamine at $26^{\circ} \mathrm{C}$ for $5 \mathrm{~d}$. The higher level of fetal bovine serum was required to promote cell adherence to each other and the formation of aggregates. An appropriate aliquot of cells were planted in uncoated cell culture flasks and incubated in L-15 media with $10 \%$ bovine serum and $1 \%$ L-glutamine at $26^{\circ} \mathrm{C}$ in preparation for the next cycle.

Microbe-free dinospore production (Friday, Day 2). Four days prior to exposing the aggregates to dinospores, tomonts were collected from an infected red drum. The protocol for collecting and producing microbe-free tomonts and dinospores has been described previously (Oestmann \& Lewis 1995). In brief, trophonts were removed by osmotic shock from infected fish placed in a clean $3.8 \mathrm{l}$ silicone coated (Sigmacote; Sigma Chemical Co., St. Louis, MO, USA) glass jar containing 0.5 I deionized water for 1 min at which time 0.5 l of SM-40 (40 ppt saltwater medium; Table 1) was added. The fish were removed after $5 \mathrm{~min}$ and the saltwater filtered through 3 layers of $102 \mu \mathrm{m}$ Nitex mesh (Sea-Gear Corp., Melbourne, FL, USA) into a siliconized 1.0 ! Erlenmeyer flask. The trophont suspension was set aside for $30 \mathrm{~min}$ to allow time for settling and transformation into tomonts. The saltwater was then aspirated to $40-50 \mathrm{ml}$ volume without disturbing the settled tomonts. The tomonts were then resuspended in the remaining saltwater and transferred into sterile siliconized test tubes and allowed to settle. The saltwater was aspirated and the tomonts washed 3 times by suspending in $10 \mathrm{ml} \mathrm{SM-30} \mathrm{(Table} \mathrm{1)} \mathrm{while} \mathrm{combining} \mathrm{set-}$ tled tomonts into 1. tube.

After the final wash the SM-30 was aspirated to a final volume of $0.5 \mathrm{ml}$. The preparation was then combined with the top $0.5 \mathrm{ml}$ of Percoll ${ }^{\circledR}$ (Pharmacia Biotech, Inc., Piscataway, NJ, USA) removed from a discontinuous density gradient formed by centrifuging $9.0 \mathrm{ml}$ of Percoll ${ }^{\circledR}$ at specific gravity 1.130 , as supplied by the manufacturer, in a $10 \mathrm{ml}$ Oak Ridge polypropylene tube (Nalgen Co., Rochester, NY, USA) for $15 \mathrm{~min}$ at $30000 \times g\left(\right.$ Percoll $^{\oplus}$; Pharmacia LKB Biotechnology 1980). The $1 \mathrm{ml}$ Percoll ${ }^{\circledR}+$ tomont suspension was gently replaced on the surface of the gradient with a siliconized Pasteur pipet and centrifuged $10 \mathrm{~min}$ at $800 \mathrm{rpm}(<200 \times q)$. The upper $9.0 \mathrm{ml}$ of the Percoll ${ }^{\circledR}$ was aspirated and the pelleted tomonts aseptically removed with a siliconized Pasteur pipet to a sterile siliconized test tube. The preparation was washed 4 times in $10 \mathrm{ml} \mathrm{SM}-30$, with 10 to 15 min settling time between washes, to remove the remaining Percoll ${ }^{\otimes}$ Tomonts were enumerated and the concentration adjusted to 5000 tomonts $\mathrm{ml}^{-1} \mathrm{SM}-30$. Six $\mathrm{ml}$ of the tomont suspension (approximately 30000 tomonts) was placed in $25 \mathrm{~cm}^{2}$ cell culture flasks and incubated at $23^{\circ} \mathrm{C}$ for $4 \mathrm{~d}$.

Cell aggregate infection (Tuesday, Day 6) and in vitro trophont growth (through Friday, Day 9). Fiveday-old RDFC aggregates were washed 3 times in SM10 (Table 1) to remove L-15 media, and aggregates from 2 flasks, in enough SM-10 to suspend, were placed in a glass siliconized Leighton tube. Microbefree dinospores from tomonts originating from the red drum were enumerated by aspirating an aliquot with a $37 \%$ formalin coated Pasteur pipet and loading onto a hemocytometer (Bower et al. 1987). The dino-

Table 1 Saltwater media (SM) formulations for cell culture propagation. Sterilized by $0.45 \mu \mathrm{m}$ filtration. Based on IO2/HBSS use by Noga (198?. 1989, 1992)

\begin{tabular}{|cccc|}
\hline & $\begin{array}{c}\text { SM-40 ppt } \\
\left(\mathrm{g} \mathrm{l}^{-1}\right)\end{array}$ & $\begin{array}{c}\text { SM-30 ppt } \\
\left(\mathrm{g} \mathrm{l}^{-1}\right)\end{array}$ & $\begin{array}{c}\text { SM-10 ppt } \\
\left(\mathrm{g} \mathrm{l}^{-1}\right)\end{array}$ \\
\hline $\mathrm{NaCl}$ & 32.38 & 24.29 & 8.10 \\
$\mathrm{MgSO}_{4} \cdot 7 \mathrm{H}_{2} \mathrm{O}$ & 6.46 & 4.85 & 1.62 \\
$\mathrm{MgCl}_{2} \cdot 6 \mathrm{H}_{2} \mathrm{O}$ & 4.65 & 3.49 & 1.16 \\
$\mathrm{CaCl}_{2} \cdot 2 \mathrm{H}_{2} \mathrm{O}$ & 1.56 & 1.17 & 0.39 \\
$\mathrm{KCl}_{\mathrm{NaHCO}}$ & 1.03 & 0.77 & 0.26 \\
$\mathrm{Na}_{2} \mathrm{HPO}_{4} \cdot 7 \mathrm{H}_{2} \mathrm{O}$ & 0.51 & 0.38 & 0.13 \\
$\mathrm{KH}_{2} \mathrm{PO}_{4}$ & 0.09 & 0.07 & 0.023 \\
Glucose & 0.06 & 0.045 & 0.015 \\
Penicillin & - & - & 1.0 \\
Streptomycin & - & $1001 \mathrm{U} \mathrm{ml^{-1 }}$ & $1001 \mathrm{U} \mathrm{ml^{-1 }}$ \\
pH & - & 7.4 & $100 \mu \mathrm{g} \mathrm{ml}$ \\
Specific gravity & $1.030 \mathrm{~g} \mathrm{ml}^{-1}$ & $1.023 \mathrm{~g} \mathrm{ml}^{-1}$ & 7.4 \\
\hline
\end{tabular}




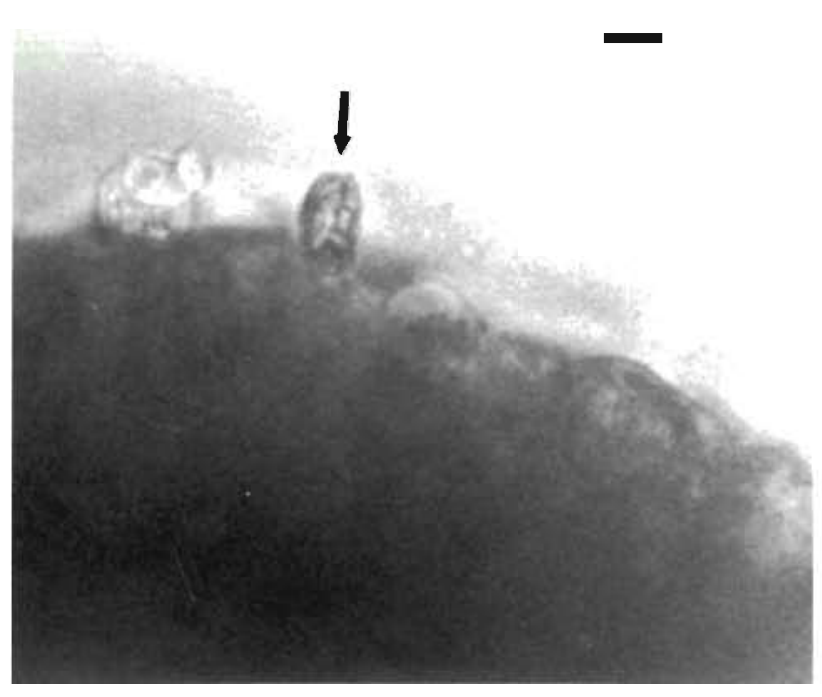

Fig. 1 Amyloodinium ocellatum. Dinospore (arrow) transforming into trophont, 10 min after exposure to red drum Sciaenops ocellatus cell aggregates. $\times 400$ (scale bar $=10 \mu \mathrm{m}$ )

spore concentration was adjusted to approximately $10000 \mathrm{ml}^{-1} \mathrm{SM}-10$.

The RDFC aggregates were infected by placing 0.5 to $1.0 \mathrm{ml}$ of the dinospore dilution into the Leighton tube. After 10 to $15 \mathrm{~min}$, excess dinospores were removed by washing 3 times with SM-10. SM-10 was placed in the Leighton tube in sufficient quantity to suspend the aggregates and verify dinospore transformation into trophonts with an inverted microscope (Fig. 1). Tubes were placed in a $23^{\circ} \mathrm{C}$ incubator on a rotary table and gently rotated to keep the aggregates suspended.
Salinity for in vitro trophont growth was decreased to $10 \mathrm{ppt}$ to approximate the osmolarity of the cell culture media. Higher salinity resulted in rapid death of the RDFC aggregates and subsequent release of undersized trophonts.

In vitro tomont collection (Friday, Day 9) and incubation (Friday through Tuesday, Days 9 through 13). After $48 \mathrm{~h}$ incubation at $23^{\circ} \mathrm{C}$ the trophonts had grown to $60-80 \mu \mathrm{m}$ (Figs. $2 \& 3$ ). The SM-10 was removed and replaced with SM-30 without antibiotics (Thursday, Day 8), causing the death of the cell aggregates. Antibiotics were not used at this point or during initial removal from infected fish because the effect on trophont transformation is unknown. Over the next $24 \mathrm{~h}$ the trophonts grew another $10 \mu \mathrm{m}$ and released from the dying cell aggregates. At $72 \mathrm{~h}$ incubation (Friday, Day 9) the Leighton tubes were washed with SM-30 to suspend the tomonts and the wash placed in sterile siliconized test tubes using a sterile siliconized Pasteur pipet. Tomonts were allowed to settle and the SM-30 aspirated. Cell debris was removed by washing 3 times with SM-30, allowing 10 to 15 min settling time between washes. Settled tomonts were then placed on a continuous density Percoll ${ }^{\circledR}$ gradient $(1 \mathrm{ml} \mathrm{SM}-30$ mixed with $9.0 \mathrm{ml}$ Percoll ${ }^{\circledR}$ specific gravity 1.130$)$ and centrifuged at $800 \mathrm{rpm}(<200 \times \mathrm{g})$ for $3 \mathrm{~min}$ to completely separate the tomonts from cell debris. The pelleted tomonts were washed as described above to remove the Percoll ${ }^{\oplus}$ (Fig. 4). Tomont concentration was adjusted to 5000 tomonts $\mathrm{ml}^{-1} \mathrm{SM}-30$ and $6 \mathrm{ml}$ placed in $25 \mathrm{~cm}^{2}$ cell culture flasks for incubation at $23^{\circ} \mathrm{C}$. At this temperature dinospores emerged from the cellculture-raised tomonts in $4 \mathrm{~d}$ (Tuesday, Day 13) and were used to infect a new set of $5 \mathrm{~d}$ old RDFC aggregates.
Fig. 2. Red drum Sciaenops ocellatus cell aggregates infected with $48 \mathrm{~h}$ old Amyloodinium ocellatum trophonts (arrows). $\times 160($ scale bar $=100 \mu \mathrm{m})$
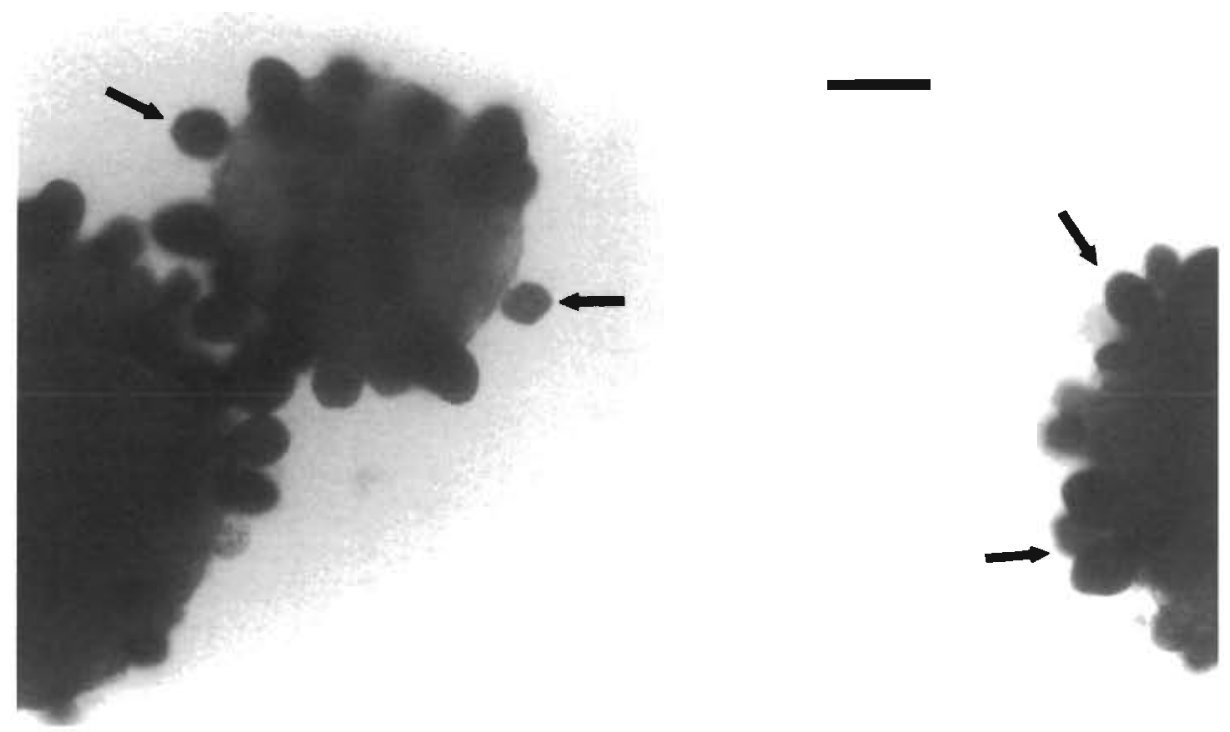


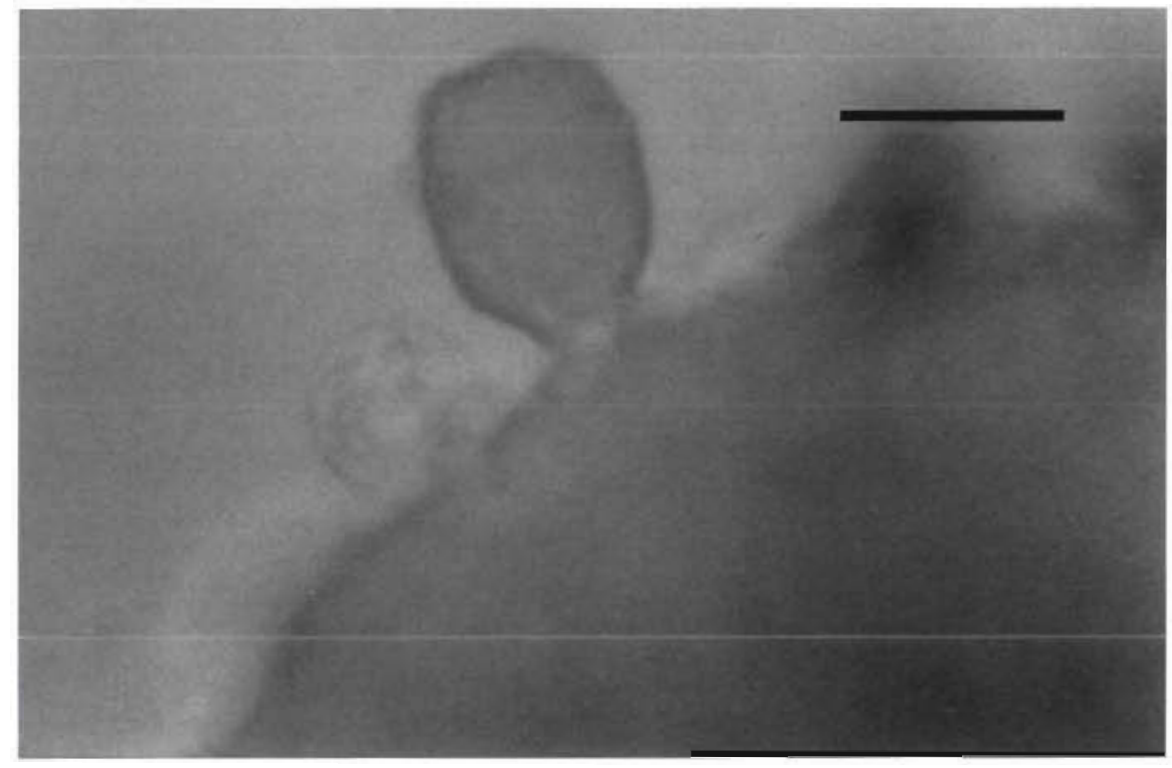

Fig. 3. Forty-eight hour old Amyloodinium ocellatum trophont on red drum Sciaenops ocellatus cell aggregate. $\times 400$ (scale bar $=50 \mu \mathrm{m}$ )

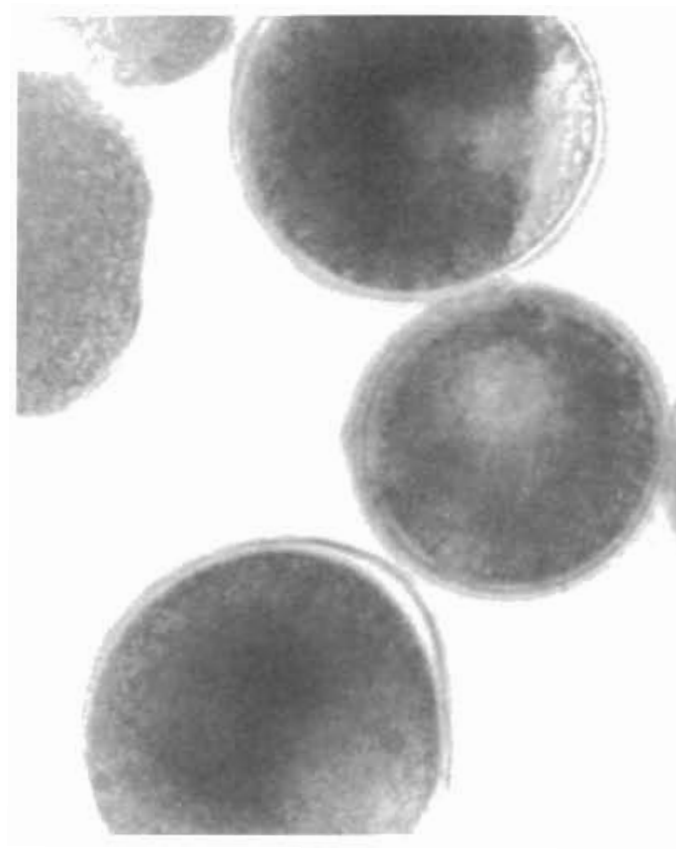

RESULTS

Amyloodinium ocellatum was maintained on cell culture for 10 passages, maintaining tomont viability between 75 and $95 \%$ with no sign of decreased viability, equaling the viability recorded for tomonts collected from in vivo infections (Oestmann \& Lewis 1995). Each cycle was completed in a $1 \mathrm{wk}$ period (aggregates infected on Tuesday, new aggregate growth started on Thursday) with tomont incubations coordinated over weekends (tomonts harvested on Friday and incubated through Tuesday). The duration of the developmental cycle is influenced by temperature. Trophonts incubated at $26^{\circ} \mathrm{C}$ grew to full size in $2 \mathrm{~d}$ and tore the aggregates apart by physical feeding action. Alternatively, at $21^{\circ} \mathrm{C}$ trophonts grew too slowly and released from the dying cell aggregates at 20 to $40 \mu \mathrm{m}$ size. Tomonts formed from small trophonts did not produce enough dinospores for efficient passage of the parasite. This protocol produced an excess of dinospores that were used for other studies, as well as to perpetuate the life cycle. The yield of dinospores is limited by the resources available to produce the RDFC aggregates. 
During preliminary investigations, tomonts removed from infected red drum were incubated in phosphate buffered saline (PBS) supplemented with penicillin (100 IU ml-1) and streptomycin $\left(100 \mu \mathrm{g} \mathrm{ml}^{-1}\right)$. Tomonts proceeded through 1 to 3 divisions after which divisions ceased and no dinospores excysted. Due to an oversight, at one point during the development of this protocol the saltwater media solutions (Table 1) were prepared without magnesium chloride. Tomonts collected from infected fish proceeded through normal division and dinospore excystment and these dinospores transformed on RDFC aggregates and grew to full size $(80$ to $90 \mu \mathrm{m})$ trophonts in magnesium deficient water. These trophonts were then collected and the tomonts incubated as described above in magnesium deficient SM-30. No divisions occurred in these tomonts and no dinospores excysted.

\section{DISCUSSION}

Amyloodinium ocellatum is a serious pathogen affecting various marine and euryhaline fish and has specifically hampered commercial development of many marine food fish and specifically red drum on the U.S. Gulf Coast. Development of effective control measures largely rests upon a better understanding of the biology of the 3 phases of the parasite life cycle and its susceptibility to various chemotherapeutics. A technique for the propagation of DC-1, a strain of A. ocellatum recovered from a pet store clown fish, have been described (Noga 1987, Noga \& Bower 1987). However the author found that isolates originating from the Texas Gulf Coast were not amenable to this procedure. Gulf Coast amyloodinium dinospores attached and transformed on G1B monolayers, but did not develop further. Dinospores transformed on red drum dorsal fin monolayers more efficiently but the resulting trophonts only grew to $40 \mu \mathrm{m}$.

Operating on the hypothesis that a 3-dimensional cellular surface, rather than a 2-dimensional monolayer, was required for optimal dinospore transformation and trophont development, efforts were directed toward utilizing cell aggregate suspensions in the propagation technique. Trypsinized red drum cells dispensed over marine agar and cultivated in L-15 media containing $15 \%$ fetal bovine serum formed aggregates which supported trophont development similar to that observed on the fish host.

Magnesium was serendipitously discovered to be a limiting requirement during the feeding stage for reproductive division of tomonts. Trophonts collected from fish maintained in artificial saltwater (Fritz SuperSalt) produced infective dinospores from tomonts incubated in magnesium deficient saltwater media. In vitro trophonts subsequently propagated in magnesium deficient saltwater media grew to full size, but the tomonts did not divide. The arrested division of tomonts incubated in PBS indicates that an interaction between tomonts and saltwater occurs. These 2 observations may provide the basis for the control of amyloodiniosis at the tomont stage by salt ion concentration manipulation using artificial salt mixes or brine well water. This is significant because the tomont stage was previously thought to be intractable to treatment since it was believed not to interact with the environment.

The described propagation technique will allow for the further study of this economically important parasite. Examples of future applications might include ultrastructural studies of the attachment process and apparatus, various metabolic studies, and screening of drugs for potential field use.

Acknowledgements. The authors thank Mrs Willie Mae Charanza for her technical support and help

\section{LITERATURE CITED}

Bower CE, Turner DT, Biever RC (1987) A standardized method of propagating the marine fish parasite Amyloodinium ocellatum. J Parasitol 73:5-88

Brown EM (1934) On Oodinium ocellatum Brown, a parasitic dinoflagellate causing epidemic diseases in marine fish Proc Zool Soc Lond Part 3, p 583-607

Brown EM, Hovasse R (1946) Amyloodinum ocellatum (Brown), a peridinian parasite on marine fish. A complementary study. Proc Zool Soc Lond 116:33-46

Lawler AR (1979) North American fishes reported as hosts of Amyloodinium ocellatum (Brown, 1931). Drum Croaker 19:8-14

Nigrelli RF (1936) The morphology, cytology and life-history of Oodinium ocellatum, a dinoflagellate parasite on marine fishes. Zoologica 21:129-164

Noga EJ (1987) Propagation in cell culture of the dinoflagellate Amyloodinium, an ectoparasite of marine fishes. Science 236:1302-1304

Noga EJ (1989) Culture conditions affecting the in vitro propagation of Amyloodinium ocellatum. Dis aquat Org 6 $137-143$

Noga EJ (1992) Immune response to ectoparasitic protozoa: the infectivity assay. In: Stolen JS, Fletcher TC, Anderson DP, Kaattari SL, Rowley AF (eds) Techniques in fush immunology. SOS Publications, Fair Haven, NJ, $p$ $167-175$

Noga EJ, Bower CE (1987) Propagation of the marine dinoflagellate Amyloodinium ocellatum under germ-free conditions. J Parasitol 73:924-928

Noga EJ, Smith SA, Landsberg JH (1991) Amyloodiniosis in cultured hybrid striped bass (Morone saxatilis X $M$ chrysops) in North Carolina. J aquat Anim Health 3: $294-297$

Oestmann DJ, Lewis DH (1995) A method for producing microbe-free Amyloodinium ocellatum (Brown) with Percoll ${ }^{\otimes}$ Vet Parasitol (in press)

Paperna I (1980) Amyloodinium ocellatum (Brown, 1931) (Dinoflagellida) infestations in cultured marine fish at 
Eilat, Red Sea: epizootiology and pathology. J Fish D1s 3 $363-372$

Paperna I (1984) Reproduction cycle and tolerance to temperature and salinity of Amyloodinium ocellatum (Brown, 1931) (Dinoflagellida). Ann Parasitol comp (Paris) 59: $7-30$

Responsible Subject Editor: W. Körting, Hannover, Germany
Pharmacia LKB Blotechnology (1980) Percoll ${ }^{\text {(3) }}$ methodology and applications, density marker beads for calibration of gradients of Percoll" Pharmacia Fine Chemicals, Uppsala 1

Sindermann CJ (1990) Principal diseases of marme fish and shellfish, Vol 1. Academic Press, New York

Manuscript first recelved: May 29, 1995

Revised version accepted: September 25, 1995 